\title{
POŠTA
}

TELEKOMUNIKÁCIE A

ELEKTRONICKY OBCHOD

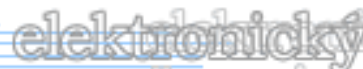

要

ERT

\section{AUTORIZAČNÉ SYSTÉMY POMOCOU TECHNOLÓGIÍ AIDC}

\author{
Juraj Vaculík ${ }^{1}$, Peter Kolarovszki ${ }^{2}$
}

\section{Úvod do autorizačných systémov}

Systémy kontroly a riadenia vstupov (Access Control System - ACS) sú integrovanou alebo autonómnou súčast'ou bezpečnostných systémov alebo systémov riadenia budov alebo celých areálov a plnia tieto základné funkcie:

- umožňujú nastavit' a riadi pohyb osôb objekte,

- monitorujú pohyb osôb v objekte, zobrazuje informácie o pohybe a aktuálnom mieste ich pobytu,

- monitorujú stavy a udalosti z jednotlivých prístupových miest,

- blokovanie opakovaného vstupu v jednom smere (anti-passback),

- funkciu vzájomného blokovania dverí,

- povolenie prístupu po identifikácii dvoch užívatel'ov a d'alšie.

Základnou požiadavkou autorizačných systémov je identifikácia a autorizácia osôb. Systém kontroly vstupov zabezpečuje kontrolovaný vstup do chránených častí objektu - pre každý objekt samostatne - na základe pridel'ovaných prístupových oprávnení.

Výkladový slovník definuje autorizáciu ako: „Postup, vedúci k poskytnutiu, alebo odmietnutiu prístupu na základe práv pridelených autoritou, alebo odmietnutia prístupu na základe práv pridelených autoritou. Spravidla jej predchádza autentifikácia, teda overenie identity“, pričom:

- Autorizáciu môžeme charakterizovat' ako proces, vktorom sa overuje aké služby, a vakom rozsahu smie využívat' subjekt, ktorý vstupuje do systému na základe identifikácie a autentifikácie ako d’alších prvkov verifikácie.

- Verifikácia je komplexný proces identifikácie a autentizácie na overovanie užívatel'a.

- Identifikácia je realizovaná priradením identifikačného prostriedku objektu v riadiacom programovom vybavení. Autorizácia osôb môže byt' prostredníctvom viacerých identifikátorov, ako napr. čipová karta, bezkontaktná karta alebo biometrický údaj.

Klasifikácia zabezpečenia je podl’a systémových požiadaviek definovaná ako nezávislá kombinácia tried identifikácie a tried prístupu. Triedy identifikácie sú od stupňa 0 po stupeň 3 podl'a nárokov na identifikáciu pričom 0 je najnižší stupeň identifikácie a stupeň 3 je najvyšší, kde sa vyžaduje kombinácia identifikačných prvkov.

- Trieda identifikácie $\mathbf{0}$ - identifikácia založená na jednoduchom požiadavku o prístup bez identity užívatel'a ( tlačidlo, kontakt, detektor pohybu),

\footnotetext{
${ }^{1}$ doc. Ing. Juraj Vaculík, PhD., Katedra spojov, FPEDAS, ŽU Žilina, email:juvac@fpedas.uniza.sk

${ }^{2}$ Ing. Peter Kolarowszki, PhD., Katedra spojov, FPEDAS, ŽU Žilina, email:peter.kolarovszki@fpedas.uniza.sk
} 
- Trieda identifikácie 1 - identifikácia založená na osobných identifikačných číslach (password - heslo), informácie uložené v pamäti, teda je známa užívatel'ovi.

- Trieda identifikácie $\mathbf{2}$ - identifikácia je založená na používaní identifikačných prvkov token - (kontaktné, čipové, magnetické, bezkontaktné karty alebo štítky, kl'úče,), alebo biometrii (obtlačok prsta, DNA, znaky tváre, tvar dlane, očná zrenica).

- Trieda identifikácie 3 - založená na používaní kombinácii identifikačných prvkov alebo biometrie a informácie uloženej v pamäti, identifikačné prvky alebo biometria spolu s informáciou uloženou v pamäti.

Autentifikáciou zist'ujeme, kto je používatel' - overenie identity. To znamená, že užívatel' predkladá overovatel'ovi dôkaz, že je tým, za koho sa prezentuje. To sa deje bud' vzájomne dohodnutým špecifickým spôsobom, alebo všeobecne uznávaným dokladom. V bežnom živote je to napríklad preukaz poistenca alebo občiansky preukaz, v elektronickom svete to môže byt' napríklad heslo, SMS kód, bezpečnostný certifikát. Autentifikácia sa podl'a spôsobu dokazovania identity objektu delí na tri základné skupiny:

- Autentifikácia na znalostnej báze (somethink to know): autentifikačnému systému predkladáme dôkaz o tom, že máme znalost' o istej informácií. Sem patrí autentifikácia všetkými druhmi hesiel a PIN kódov. Heslo sa systému predkladá bud' priamo $\mathrm{v}$ otvorenej forme, alebo sa pri dokazovaní jeho znalosti vyžaduje istý spôsob interakcie (systémy výzva - odpoved'). V prípade autentizácie je možné následne zadat' napríklad tajné heslo.

o Výhodou tohto spôsobu identifikácie je jednoduchá realizácia snímacieho zariadenia.

o Nevýhodou sú nároky na užívatel'a (identifikovanú osobu), ktorý si musí pamätat' tajné heslo alebo PIN kód

- Autentifikácia na báze vlastníctva (something to have): predkladáme dôkaz o vlastníctve identifikačného prvku. Do tejto kategórie patria všetky systémy čipových a magnetických kariet, prístupových kalkulátorov a hardvérových klúčov. Dôkaz o vlastníctve predmetu sa väčšinou realizuje nepriamo, dokazovaním vlastníctva informácií uložených na predmete (prístupové kalkulátory), alebo poskytnutím celého predmetu na preskúmanie (karty s magnetickým prúžkom).

o Výhodou tohto spôsobu autentizácie sú menšie nároky na identifikované osoby stačí aby vo vhodnej chvíli priložili identifikačný predmet k čítaciemu zariadeniu, nemusia si pamätat’ žiadne kódy.

o Nevýhodou spôsobu sú vyššie nároky na autentizáciu - sú potrebné identifikačné predmety a špeciálne čítacie zariadenia. Z hl'adiska bezpečnosti je hlavnou nevýhodou možnost' straty alebo odcudzenia identifikačného predmetu a následná hrozba jeho zneužitia.

- Autentifikácia na báze danosti (something to be): Dokazujeme svoju identitu pomocou neoddelitel'ného fyzického základu. Do tejto kategórie patria všetky biometrické metódy a dokazujú identitu človeka na základe jeho vonkajších telesných znakov (zrenica, dúhovka, odtlačok prstu), alebo jeho životných prejavov (analýza reči, podpisu).

o Hlavnou nevýhodou tohto spôsobu identifikácie sú vysoké náklady na realizáciou autentizačného systému - ako snímača biometrickej vlastnosti, tak následnej digitalizácie vzorky a spracovanie zosnímanej informácie.

o Výhodou je vysoká bezpečnost' identifikácie alebo verifikácie.

Metódy AIDC môžeme zaradit' medzi metódy autentifikácie na báze vlastníctva (čiarové kódy, smart karty, RFID) a na báze danosti (biometria). Ked’že tieto metódy sa aj v reálnom použití navzájom kombinujú a dopĺnajú. Tieto systémy majú rozličné režimy verifikácie, z globálneho hl'adiska pracujú na rovnakom princípe. V prvom rade ide o zistenie totožnosti používatel'a, následne porovnanie načítaných dát $\mathrm{s}$ údajmi v databáze a nakoniec 
priradenie prístupových práv. V prípade použitia autentizácie vlastníctvom identifikačného predmetu môžeme spôsoby identifikácie členit' podl'a technológie média. Vlastná technológia identifikačného média súvisí s fyzikálnym princípom prenosu informácie medzi prvkom autentizácie a snímačom. V zásade možno médiá rozdelit' na:

- optické (čiarový kód, OCR),

- magnetické (karty s magnetickým pruhom),

- induktívne (karty s kovovými prvkami),

- pamätové čipy (čipové karty, prívesky),

- rádiofrekvenčné (RFID identifikátory)

\section{Autorizačné systémy s čiarovými kódmi}

Systémy s čiarovými kódmi sú masívne rozšírené. Sú využívané vo všetkých oblastiach spoločnosti. Tieto systémy sú navrhnuté a konštruované v rôznych vel'kostiach a usporiadaniach. Komplexnost' požadovaná systémom je determinovaná aplikáciou. Základný skenovací systém môžeme fundamentálne rozložit' na štyri komponenty (obr. 1).

a) Tlačiareň čiarových kódov - prvým komponentom v tomto systéme je tlačiareň kódov. Ked’že čiarové kódy sú dostatočne odolné a l’ahko implementovatelné, preto aj konštrukcia a technológia tlačiarní je rôznorodá. Z konštrukčného hl'adiska sa používajú laserové a atramentové tlačiarne. Špecializované tlačiarne, určené len na tlač čiarových kódov pracujú s vyšším tlačiacim výkonom a kvalitou (napríklad Zebra, Datamax, Intermec). Na tlač môžeme použit’ aj špeciálny softvér (napríklad Zebra Bar One).

b) Štítok s kódom - na vytlačenie tohto štítka sa používa už popísaná tlačiareň, a na vytvorenie softvér na tvorbu čiarových kódov. Pod pojmom štítok rozumieme papierovú nálepku, papierový preukaz alebo plastovú kartu. Tieto štítky môžu obsahovat' okrem čiarového kódu aj l’ubovol'ný text, grafiku, alebo d’alší doplňujúci údaj. Umiestňujú sa na daný výrobok v prípade tovaru a použitie vo forme karty pre l’udí a týmto zabezpečíme sledovanie.

c) Skenovacie zariadenia pre zber dát - fáza zberu dát prechádza od použitia skenerov, ktoré priamo a presne čítajú, zachytávajú a dekódujú informáciu obsiahnutú v čiarovom kóde. Používajú sa dva typy skenerov - kontaktné a bezkontaktné. Pri skeneroch musíme rozlišovat' ešte jeden atribút - či je dekódovací, alebo nie je dekódovací. To znamená, že dekódovacie skenery majú zabudované hardvérové dekodéry, ktoré transformujú význam čiarového kódu do počítačom zrozumitel'nej formy ešte pred odoslaním do počítača. Nedekódovacie skenery obsahujú iba svetelný zdroj a jednotku na zachytenie dát, ktoré sú následne odosielané do dekodéra.

d) Záznam dát do databázy - posledným komponentom pri zavádzaní jednoduchého systému s čiarovým kódom je databáza. To, že sme úspešne vytvorili a naskenovali čiarové kódy neznamená, že sme dokončili celý cyklus na vytvorenie kompletného a efektívneho systému. Na efektívne využívanie kódov je nevyhnutná databáza, ktorá nám poslúži na výmenu a obnovovanie informácií. Do tejto databázy sú importované záznamy pri tvorbe kódov, ktoré môžu byt' neskôr využívané pre prístup, kontrolu, identifikáciu a podobne. 


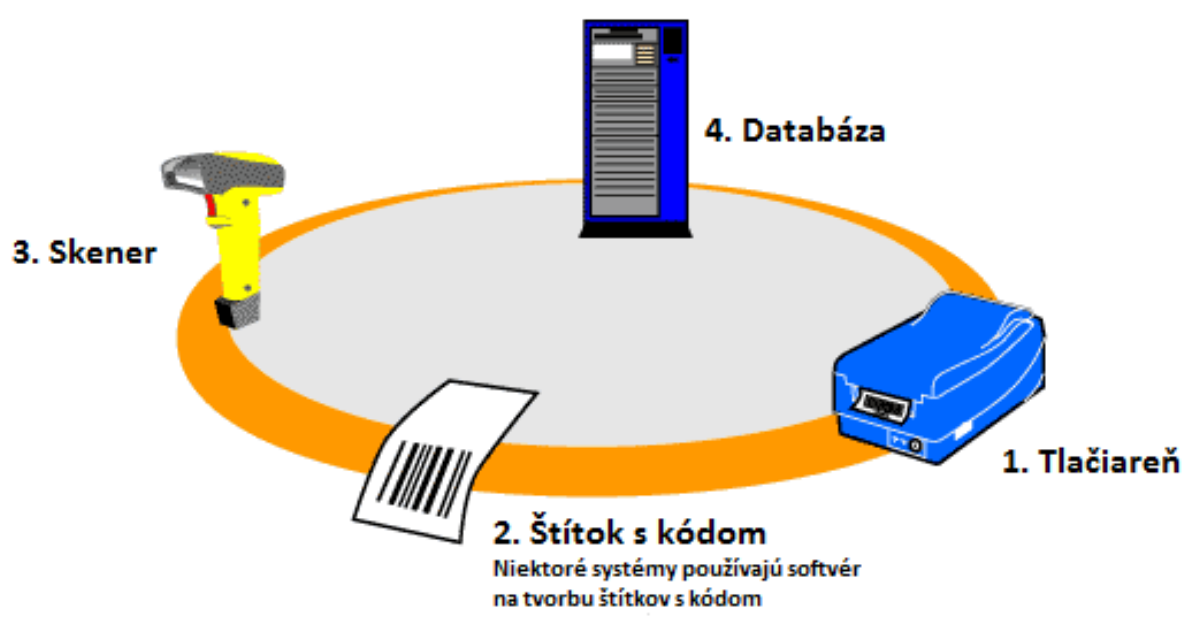

Obr. 1 Autorizačný systém s čiarovými kódmi (Zdroj: Barcodes for beginners. [online]. Dostupné na internete: < http://www.systemid.com/barcode_learning_center/beginners.asp>.)

Rozklad systému na jednotlivé komponenty umožňuje popísat' funkčnost' systému ako celku. Verifikačný proces sa začína vytvorením identifikačnej karty, na ktorej je čiarový kód. Hodnota tohto čiarového kódu spolu s dátami v ňom zakódovanými a autorizačnou funkciou sú uložené v databáze a sú priradené konkrétnemu objektu. Následne je karta odovzdaná do prevádzky. Objekt, ktorý pristupuje do autorizačného systému priloží identifikačnú kartu $\mathrm{k}$ skeneru. Ten prečíta kód, dekóduje informáciu a v databáze porovná zhodu s uloženými položkami. Následne potvrdí alebo zamietne prístupové práva.

\section{Autorizačné systémy s biometriou}

Biometrický autorizačný systém charakterizujeme ako systém, ktorý umožňuje nasnímat' jednotlivé biometrické vzorky, čiže údaje reprezentujúce biometrickú vlastnost' užívatel'a. Získané údaje systém spracuje a porovnáva s jednou, alebo viacerými referenčnými šablónami v systéme. Na základe tohto porovnávania rozhodne, na kol'ko percent sa obidve vzorky zhodujú a indikuje totožnost', alebo netotožnost'.

Biometrické identifikačné a verifikačné systémy identifikujú, alebo verifikujú priamo identitu človeka, nie predmety, kódy alebo heslá. Tieto technológie sa odlišujú na základe toho, čo a akým spôsobom snímajú, ale princíp ich fungovania je v podstate identický. Pomocou snímacieho zariadenia, sú nasnímané identifikačné biometrické znaky. Na základe presne stanovených algoritmov a vopred nasnímaných autentických obrazov vyberú potrebné prvky, z ktorých sa vytvorí šablóna.

V tomto systéme ide o určenie stupňa pravdepodobnosti, že získané biometrické znaky určujú totožnost' požadovanej osoby. Dôležité je určenie stupňa, ktorý rozhoduje, či je prekročená stanovená medzná hodnota. Biometrické systémy plnia dve hlavné funkcie:

1. Identifikácia - porovnávajú vstupnú vzorku s databázou a identifikujú zhodu $\mathrm{z}$ množiny všetkých vzoriek. Táto metóda sa používa v prípadoch, ked' identifikovaná osoba systému vopred nie je známa.

2. Verifikácia - slúži pre overenie identity systému vopred známej osoby. V tomto prípade je potrebné porovnat' len vzory, teda vstupný vzor s uloženým vzorom pre identifikovanú osobu.

Každý druh biometrického systému je závislý vo väčšej, či menšej miere na príslušnom biometrickom znaku, ktorý je skúmaný. Tieto systémy sa skladajú z jednotlivých komponentov.

a) Snímacie zariadenie - slúži pre akvizíciu biometrických dát a pre ich konverziu do digitálnej podoby, 
b) Algoritmy pre spracovanie signálu - spracovávajú vstupné dáta a generujú biometrické vzorky,

c) Databáza - uchováva vzorky, ktoré slúžia ako podklad pre autentifikáciu,

d) Algoritmy pre porovnávanie vzorov - vyhodnocujú porovnanie vstupného biometrického vzoru s uloženými vzormi v databáze,

e) Rozhodovací proces - slúži pre podporu konečného rozhodnutia o úspechu, alebo neúspechu autentifikácie.

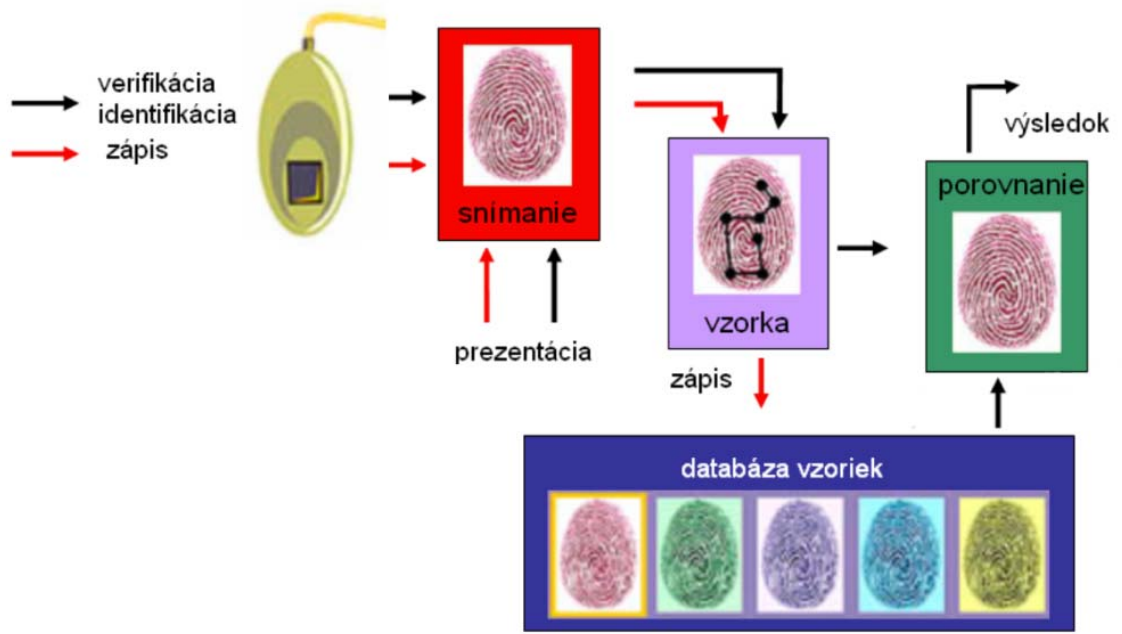

Obr. 2 Autorizačný Systém s biometriou (Zdroj: Princípy biometrie. [online]. Dostupné na internete: < http://www.biometria.sk/principy-biometrie.html>.)

Biometrické systémy, ktoré pracujú s odtlačkami prstov vo svojej primárnej podstate využívajú prvky daktyloskopie. Daktyloskopia je kriminalistická metóda, ktorá skúma obrazy papilárnych línií na vnútornej strane článkov prstov, prípadne dlaní alebo chodidiel.

Papilárne línie vytvárajú obrazce, podl'a ktorých je možné stanovit' niekol'ko vzorov. Takto vytvorené vzory slúžia na základné rozdelenie obrazcov. Odtlačky prstov sa vytvárajú vylučovaním potu z kanálikov papilárnych línií prstov rúk a spravidla bývajú bezfarebné. Pre identifikáciu jednotlivca pomocou snímania odtlačku prsta existujú v podstate dva základné typy technológií:

- Optická metóda,

- Ostatné metódy využívajúce polovodičmi generované elektrické pole.

Podstatou optickej metódy je vizuálny obraz prsta. Štruktúra optického snímania odtlačku prstov je nasledovná: svetlo zo zdroja sa odráža od dotykovej plochy a odrazené svetlo zachytí šošovka, ktorá pošle informáciu snímaciemu a archivačnému zariadeniu. Zariadenie spracuje odtlačok prsta pomocou ultrafialového lúča vysielaného snímačom. Následne sa prekonvertuje na digitálny signál a uloží do databázy vzoriek.
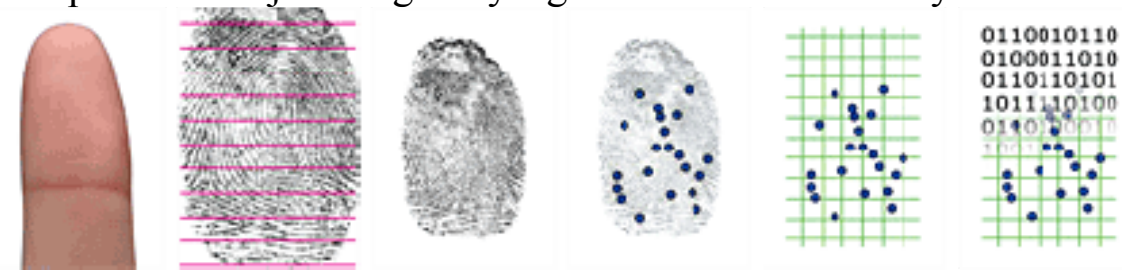

Obrázok 1 Postupnost' spracovania odtlačku prsta (Zdroj: Biometria - najbezpečnejšia alternatíva. [online]. [cit. 2011-02-19]. Dostupné na internete: < http://www.ekey.sk/index.php?page=ekey-

\section{Autorizačné systémy so smart kartami} home >.)

Pod pojmom „smart card“ (čipová karta) rozumieme integrovaný obvod, zalisovaný v nosiči a obsahujúci procesor s pamät’ou a operačný systém čipu a pod.. 
Čipové karty môžu obecne slúžit' $\mathrm{k}$ ukladaniu l’ubovol'ných dátových štruktúr (pamät'ové čipové karty), v dnešných časoch sa udomácňujú kryptografické čipové karty, ktoré slúžia k ukladaniu kl'účového materiálu prípadne k operáciám s týmito kl'účmi.

Dôležitá odlišnost' smart karty spočíva v tom, že smart karta vykonáva nielen uloženie, ale aj spracovanie dát obsahujúcich informácie. Obsah čipu smart karty je dôkladne chránený od cudzieho prístupu. Je to jedna z hlavných výhod smart karty. Smart karty sa rozdel'ujú do kategórií:

- typ čipu;

- spôsob čítania informácií z karty;

- oblast' využitia.

V závislosti od zabudovaného čipu rozdel'ujeme smart karty na dva základné typy:

- pamät'ové karty;

- mikroprocesorové karty.

Najjednoduchšie čipové karty sú pamät'ové karty, ich čip slúži iba ako pamät'ové médium. Všeobecne sú označované ako pamät’ové karty („Memory Cards“), karty s uloženou hodnotou („Stored-Value Memory Cards“) alebo tiež podl'a účelu použitia - predplatitel'ské karty („Prepaid Cards“). Čipové karty môžu obsahovat' pamät’ rôznych typov (RAM, ROM, PROM, EPROM, EEPROM) s rôznym stupňom ochrany.

Mikroprocesorové karty („Microprocessor Cards“) - čipové karty s vlastnou aktívnou inteligenciou. Tá je vytvorená mikroprocesorom, ktorý je schopný vykonávat’ rôzne operácie s dátami uloženými v pamäti čipovej karty (RAM, ROM, EEPROM). Základný operačný systém je uložený v ROM, ale pamät' EEPROM, až 10000 krát preprogramovatel'ná, môže obsahovat' vel'ký počet aplikácií. Dáta môžu byt' uložené v EPROM i EEPROM pamäti a RAM pamät' môže procesor použit' pre svoje výpočtové operácie a medzivýsledky. Procesor je vel'mi užitočný pre bezpečnost', výrazne silnejšiu autentizáciu, výpočty nutné pre digitálny podpis, šifrovanie komunikácie medzi kartou a (platobným) terminálom. Procesor môže ukladat' dáta do pamäte EEPROM v šifrovanom tvare.

Podl'a spôsobu čítania informácie z karty sa rozlišujú nasledujúce typy smart kariet:

- Kontaktné čipové karty - pre komunikáciu je kartu nutné vložit’ do čítačky tak, aby došlo k prepojeniu vodivých kontaktov,

- Bezkontaktné čipové karty - vybavené bezkontaktným rádiovým rozhraním pracujúcom na princípe elektromagnetickej indukcie a prenosu informácií elektromagnetickým pol’om, ktoré slúži zároveň pre napájanie čipu v karte,

- Hybridné karty - karta vybavená dvoma čipmi, kontaktným a bezkontaktným,

- Duálne karty - kontaktné a bezkontaktné rozhranie obsluhuje jeden čip.

Oblast' využitia smart kariet ovplyvňujú vlastnosti ako pohodlie, spol'ahlivost' a multifunkčnost' a preto tieto vlastnosti umožňujú široké spektrum použitia. Smart karty nachádzajú uplatnenie v mnohých oblastiach:

- Telefóny - platobné karty pre telefónny automat, SMS, GSM SIM karty

- Doprava - cestovné lístky;

- Zdravotníctvo - zdravotná karta, karta poistenia;

- Zákaznícka karta - vernostný program (zl’avy a bonusy).

\section{Autorizačné systémy s technológiou RFID}

Prínos technológie RFID je ten, že nie je potrebná priama viditel'nost' - to znamená, že produkt môže byt' skenovaný aj cez plastové obaly, pričom identifikátory nemusia byt' vôbec natočené priamo $\mathrm{k}$ čítačke. Týmto načítaním sa odbúrava l'udská práca, kedy sa napríklad paleta alebo produkt s identifikátorom naskenuje aj ked' dopravný pás nesie náklad okolo čítačky. 
Pri tvorbe aplikácií spravidla spoločnost' vytvorí siet' RFID čítačiek napríklad okolo dverí, nákladných rámp a v skladoch. Ked' manipulujeme s paletou a presunieme ju cez bránu, je načítaný jej identifikátor, ktorý je poslaný na aplikačný server. Ten si nájde obsah palety a priradí obsah palety do skladu. Následne sa paleta uloží do skladu napríklad Sklad A, Ulička 2, Regál A3 stred. Všetky tieto dáta zaznamená systém čítačiek a systém dokáže ihned' poskytnút' informácie, kde sa daný produkt nachádza. Špeciálnou vlastnost’ou tohto systému je možnost' hl'adat' výrobok aj opačným smerom, teda kde sa produkt s určitým EPC číslom nachádza. Má to význam napr. pri sledovaní záručných dôb, kde sú v prvom rade vyskladňované produkty s kratšou dobou záruky.

Aby sa informácie o výrobkoch nemuseli zadávat' ručne, existuje siet' EPC Network. V tejto sieti je možné vyhl'adávat' výrobky podl'a mena. Na prepojenie medzi menom a kódom slúži služba ONC - „Object Name Service“ obdoba DNS v klasickom svete počítačov.

V aplikačnom systéme sa o výrobku vytvára PML - „Physical Markup Language“ záznam pričom PML je založené na základe jazyka XML. Je dôležité, aby aplikácie vyhodnocovali viacnásobné načítanie a manipuláciu s produktmi na základe porovnania EPC kódu. Môže sa totiž stat', že paleta alebo produkt s čipom prejde dvakrát okolo čítačky a to by znamenalo, že načítaním by došlo k nezhode so skutočným stavom.

Najviac rozšírené oblasti použitia patrí označovanie kartónov, paliet, kontejnerov a to nielen pre potreby distribučných firiem, ale aj obchodných ret’azcov. Vo vývoji sú napríklad aplikácie na kontrolu vyprázdňovania odpadových nádob na triedený alebo netriedený odpad. Pre maloobchodný predaj je zaujímavá aplikácia účtovania na pokladni, to znamená, že všetko by načítal skener na pokladni v krátkom okamihu, čím by sa radikálne urýchlil prechod cez pokladňu. V pol'nohospodárstve sa označujú zvieratá čipmi RFID na identifikáciu alebo vyhl'adávanie.

\section{Záver}

Príspevok sa zaoberá možnost'ami aplikácie technológií automatickej identifikácie do oblasti autorizácie osôb, riadenia prístupu, monitorovania obehu tovaru a osôb. Zaujímavou je aplikácia technológie RFID do tejto oblasti s ktorou sa ešte podrobnejšie stretneme po jej otestovaní v laboratóriu AIDC.

\section{Literatúra}

[1] CZORIČ L.: Návrh autorizačného systému pomocou technológie RFID, diplomová práca, Žilinská univerzita, 2011

[2] LOVEČEK T., Bezpečnostné systémy: bezpečnost' informačných systémov, vysokoškolská učebnica, 1. vyd. - V Žiline : Žilinská univerzita, 2007, ISBN 978-808070-767-5.

[3] MADLEŇÁK R., Elektronický obchod, skriptá, ŽU v Žiline, F PEDAS, 2004. ISBN 808070-192-X

[4] ŠVADLENKA L., MADLEŇÁK, R. Elektronické obchodování. Pardubice : Institut Jana Pernera, 2007. ISBN 80-86530-40-X,

\section{Grantová podpora:}

- 077-059ŽU-4/2010 - Implementácia nových technológií do vzdelávania (vytvorenie RFID laboratória ako podporného prvku pre vzdelávanie)

- 1/0149/10 Difúzne procesy nových mobilných služieb a ich hodnotový ret'azec

- OPV-2009/1.2/01-SORO - Systematizácia pokrokových technológií a poznatkov medzi priemyselnou sférou a univerzitným prostredím

- 089-068ŽU-4/2010 Aplikácia RFID pri sledovaní pohybu diplomových a bakalárskych prác $\mathrm{v}$ rámci univerzitného campusu 